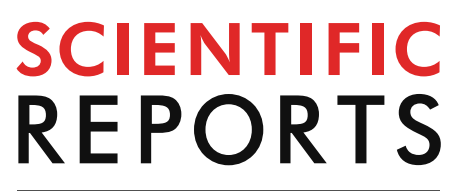

natureresearch

Check for updates

\title{
Effects of legume-diet and sex of ducks on the growth performance, physicochemical traits of meat and fatty acid composition in fat
}

\author{
Emilia Kowalska, Joanna Kucharska-Gaca, Joanna Kuźniacka®, Jakub Biesek® ${ }^{\circledR}$, \\ Mirosław Banaszak [1] \& Marek Adamski (i)
}

Duck meat enjoys growing popularity among consumers. Alternative protein sources to soybean are being investigated to eliminate genetically modified components from the poultry' diet. The aim of this study was to compare growth performance, quality of meat, and fatty acid composition in subcutaneous and abdominal fat from ducks fed a diet based on yellow lupin and rapeseed meal, sources of protein alternative to soybean meal (SBM). Ducks were allocated to different dietary treatment groups and reared for 8 weeks ( $N=102$ per group). Group A received a diet based on SBM, while group B was fed a diet based on yellow lupin with the addition of rapeseed meal. Both groups were divided into two subgroups, of male and female birds. Growth performance parameters and zoometric traits of ducks were monitored during the growth period. After 8 weeks selected birds were slaughtered and dissected ( $N=10$ per group). Carcass composition was calculated and selected traits of meat quality important for further processing were analysed. Subcutaneous and abdominal fat were collected to analyse fatty acid composition. The alternative diet had no negative effect on ducks' growth performance parameters and dressing percentage. The replacement of SBM with yellow lupin and rapeseed meal increased $n-3$ fatty acid content, which is important for consumers. In conclusion, SBM can be replaced with feed containing $60.10 \%$ of yellow lupin and $14.00 \%$ of rapeseed meal in concentrate. These sources of protein are mainly recommended for small poultry farms, which do not always have access to SBM and prepare poultry feed from their own crops.

Pekin ducks are one of the most popular breeds of waterfowl in the world kept for meat ${ }^{1}$. They are characterized by high growth performance, and there are different strategies for rearing these ducks ${ }^{2,3}$. Growth performance and the quality of meat largely depend on diet and the choice of appropriate feed components ${ }^{4}$. Diet also influences the content of fatty acids in meat and fat, which is important in the context of consumers' health ${ }^{5}$. Generally, SBM is the main source of protein in poultry diets, but it is usually obtained from genetically modified plants and its use is now raising concerns among consumers ${ }^{6}$. Studies have not provided compelling evidence on the negative effects of animal diets based on $\mathrm{SBM}^{7}$. Nevertheless, increasing soybean prices prompted researchers to investigate other sources of protein suitable for animal diets ${ }^{8}$. Biesek et al. ${ }^{9}$ concluded that legumes, particularly lupin seeds, are a promising source of protein for poultry diets, although they do not provide sufficient amounts of starch or easily digestible carbohydrates. In the past, the use of legume seeds was limited because of their high content of antinutrients, despite the fact that lupins, depending on the cultivar, contain approx. $40 \%$ of protein. However, new varieties of lupin created in breeding studies are characterised by much lower levels of antinutrients deteriorating growth performance in poultry ${ }^{10-12}$. Another alternative source of energy and protein is rapeseed meal $(\mathrm{RSM})^{7}$, a by-product of rape processing ${ }^{13}$. RSM is rich in protein $(34 \%)$, and is easily available for the production of animal feed, but it also contains antinutrient glucosinolates and therefore 


\begin{tabular}{|c|c|c|c|c|c|}
\hline Group & Sex & Mortality (\%) & $\begin{array}{l}\text { FCR per } \mathrm{kg} \text { of body weight gain } \\
(\mathrm{kg} / \mathrm{kg})\end{array}$ & $\begin{array}{l}\text { FI-feed intake per duck during } \\
\text { growth (kg) }\end{array}$ & European Broiler Index (EBI) \\
\hline \multirow{2}{*}{ A } & $\hat{\partial} \hat{O}$ & 1.56 & 3.11 & 10.49 & 192.18 \\
\hline & 우우 & 3.28 & 3.13 & 10.00 & 177.13 \\
\hline \multirow{2}{*}{ B } & $\hat{\partial} \hat{\sigma}$ & 7.81 & 3.21 & 10.06 & 158.14 \\
\hline & 우우 & 4.84 & 3.30 & 9.86 & 156.02 \\
\hline
\end{tabular}

Table 1. Growth performance parameters in ducks. $A$ ducks fed a diet based on soybean meal; $B$ ducks fed a diet based on yellow lupin and rapeseed meal; $\delta^{\lambda} \delta^{\lambda}$ Males, + + Females.

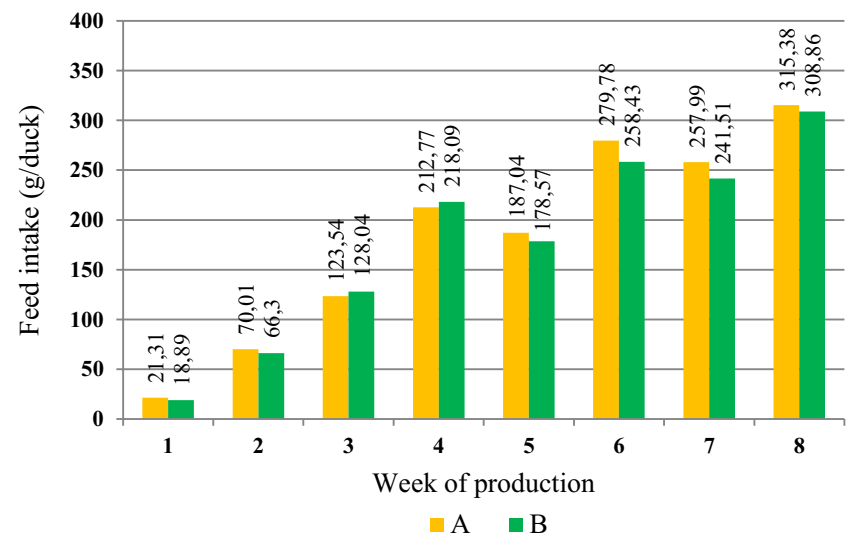

A - control group fed soybean meal; B - treatment group fed lupin-rich feed

Figure 1. Mean daily feed intake (g/duck) during growth.

cannot replace SBM completely ${ }^{14}$. Hang et al. ${ }^{13}$ concluded that the addition of vitamins to feed with a 5 or $10 \%$ inclusion of RSM can minimize the negative effects of antinutrients. Kuźniacka et al. ${ }^{12}$ compared the effects of diets containing different sources of protein on the quality of meat from ducks. The best quality parameters were found in ducks fed diets with 57.78-42.22\% inclusions of yellow lupin and 17.87-34.49\% inclusions of RSM in starter and grower feeds, respectively. Similar results were reported by Banaszak et al. ${ }^{15}$, who proposed a $68.98 \%$ inclusion of yellow lupin in feed concentrate for ducks. The researchers concluded that the proposed feed ration can partly substitute SBM, since it had no negative effect on most quality traits of meat, while yellow lupin had a positive effect on fatty acid composition in breast muscles from ducks.

Tested hypothesis: A diet with a $60.10 \%$ inclusion of yellow lupin and a $14.00 \%$ inclusion of rapeseed meal as substitutes for SBM influences growth performance parameters, meat quality and fatty acid composition in fat from ducks.

The aim of this study was to compare growth performance, quality of carcass and meat, and fatty acid composition in subcutaneous and abdominal fat from ducks fed a diet based on yellow lupin and rapeseed meal used as sources of protein alternative to SBM.

\section{Results}

Growth performance. Growth performance parameters are presented in Table 1. Data were not analysed with statistical methods. Mortality of ducks differed between dietary treatment groups and sexes. The highest mortality was found in males from group B (7.81\%), and the lowest in males from group A (1.56\%). All cases of mortality were recorded at the early rearing period (weak ducklings). Feed conversion ratio (FCR) in all groups ranged from 3.11 to $3.30 \mathrm{~kg} / \mathrm{kg}$. Feed intake (FI) was from $10.49 \mathrm{~kg}$ in males from group A to $9.86 \mathrm{~kg}$ in females from group B. The mean daily feed intake is presented in Fig. 1. For each week of production; no significant differences were noted. Daily feed intake was $18.89-21.31 \mathrm{~g}$ in week 1 and 308.86-315.38 g in week 8. Body weight of ducks (Table 2) in weeks 2-8 differed between treatment groups $(P=0.000)$, and was significantly higher in group A. Body weight in weeks 5 and 8 was significantly higher in male ducks $(P=0.000)$. There was also an interaction between performance variables in weeks 1 to $5(P=0.001 ; P=0.000)$. Despite differences in body weight in subsequent weeks of production between dietary treatments and sex of ducks, body weight gain (BWG) in treatment groups at the end of the rearing period was comparable $(P>0.05)$. BWG was significantly higher in male ducks than in females $(P=0.000)$. Significant differences between groups A and B were found in weeks $2,3,5$ and 6 of production (BWG was higher in group A), while differences between sexes were found in the same weeks as for treatment groups, except week 8 . There was also an interaction effect between parameters recorded in weeks $1,2,4$ and 6 (Table 3 ). The analysis of data in Table 4 presenting zoometric traits and body conformation indices of ducks revealed sex-associated differences: body length, wing length, compactness index and long-leggedness index were significantly higher in males than in females. A significant interaction between variables analysed in the experiment was found for chest circumference and massiveness index $(P=0.032 ; P=0.002)$. 


\begin{tabular}{|c|c|c|c|c|c|c|c|c|}
\hline \multirow[b]{2}{*}{ Age (week) } & \multicolumn{2}{|l|}{ Group } & \multirow[b]{2}{*}{ V (\%) } & \multicolumn{2}{|l|}{ Sex } & \multicolumn{3}{|l|}{$P$ value } \\
\hline & A & B & & $\hat{\partial} \hat{O}^{-}$ & q9 & Group & Sex & Interaction \\
\hline 0 & 60.59 & 61.22 & 7.64 & 61.15 & 60.66 & 0.295 & 0.420 & 0.345 \\
\hline 1 & 140.40 & 140.08 & 14.52 & 139.69 & 140.78 & 0.906 & 0.688 & $0.000^{x}$ \\
\hline 2 & $454.33^{\mathrm{a}}$ & $399.64^{\mathrm{b}}$ & 19.11 & 417.44 & 436.97 & 0.000 & 0.078 & $0.000^{x}$ \\
\hline 3 & $830.92^{\mathrm{a}}$ & $719.14^{\mathrm{b}}$ & 16.93 & 777.93 & 773.59 & 0.000 & 0.737 & $0.001^{x}$ \\
\hline 4 & $1,411.34^{\mathrm{a}}$ & $1,314.96^{\mathrm{b}}$ & 15.13 & \begin{tabular}{|l|}
$1,359.21$ \\
\end{tabular} & \begin{tabular}{|l|}
$1,368.19$ \\
\end{tabular} & 0.000 & 0.771 & $0.001^{x}$ \\
\hline 5 & $1901.13^{\mathrm{a}}$ & $1741.66^{b}$ & 13.98 & $1786.05^{\mathrm{b}}$ & $1857.84^{\mathrm{a}}$ & 0.000 & 0.041 & $0.000^{x}$ \\
\hline 6 & $2,571.75^{\mathrm{a}}$ & $2,327.86^{\mathrm{b}}$ & 11.72 & \begin{tabular}{|l|}
$2,456.27$ \\
\end{tabular} & \begin{tabular}{|l|}
$2,446.53$ \\
\end{tabular} & 0.000 & 0.731 & 0.145 \\
\hline 7 & $3,005.39^{\mathrm{a}}$ & $2,788.42^{\mathrm{b}}$ & 10.25 & \begin{tabular}{|l|}
$2,922.00$ \\
\end{tabular} & \begin{tabular}{|l|}
$2,875.00$ \\
\end{tabular} & 0.000 & 0.196 & 0.829 \\
\hline 8 & $3,307.63^{\mathrm{a}}$ & $3,096.28^{\mathrm{b}}$ & 9.29 & $3,285.94^{\mathrm{a}}$ & $3,122.67^{\mathrm{b}}$ & 0.000 & 0.000 & 0.526 \\
\hline
\end{tabular}

Table 2. Means ( $\mathrm{g}$ ) and coefficients of variation (\%) for body weight in subsequent weeks of duck growth $(\overline{\mathrm{x}}$, $\mathrm{V})$ (number of ducks: $\mathrm{N}=102$ per group). $A$ ducks fed an SBM-based diet; $B$ ducks fed a diet based on yellow lupin and rapeseed meal. ${ }^{\mathrm{a}, \mathrm{b}}$ Means in rows marked with different letters differ significantly between groups $(P \leq 0.05)$. ${ }^{\mathrm{x}}$ Significant group: sex interaction $(P \leq 0.05)$.

\begin{tabular}{|l|l|l|l|l|l|l|l|}
\hline \multirow{2}{*}{ Age (week) } & \multicolumn{3}{l}{ Group } & Sex & \multicolumn{2}{l|}{ Pvalue } \\
\cline { 2 - 9 } & A & B & Males & Females & Group & Sex & Interaction \\
\hline 1 & 79.81 & 78.86 & 78.53 & 80.12 & 0.702 & 0.528 & $0.000^{\mathrm{x}}$ \\
\hline 2 & $313.93^{\mathrm{a}}$ & $259.56^{\mathrm{b}}$ & $277.75^{\mathrm{b}}$ & $296.19^{\mathrm{a}}$ & 0.000 & 0.043 & $0.003^{\mathrm{x}}$ \\
\hline 3 & $376.60^{\mathrm{a}}$ & $319.50^{\mathrm{b}}$ & $360.49^{\mathrm{a}}$ & $336.63^{\mathrm{b}}$ & 0.000 & 0.009 & 0.103 \\
\hline 4 & 580.42 & 595.83 & 581.28 & 594.60 & 0.295 & 0.358 & $0.017^{\mathrm{x}}$ \\
\hline 5 & $489.79^{\mathrm{a}}$ & $426.70^{\mathrm{b}}$ & $426.84^{\mathrm{b}}$ & $489.65^{\mathrm{a}}$ & 0.004 & 0.005 & 0.118 \\
\hline 6 & $670.62^{\mathrm{a}}$ & $583.53^{\mathrm{b}}$ & $667.55^{\mathrm{a}}$ & $588.69^{\mathrm{b}}$ & 0.007 & 0.013 & $0.031^{\mathrm{x}}$ \\
\hline 7 & 433.64 & 460.55 & 465.85 & 428.47 & 0.253 & 0.116 & 0.051 \\
\hline 8 & 302.24 & 307.86 & $363.82^{\mathrm{a}}$ & $247.67^{\mathrm{b}}$ & 0.806 & 0.000 & 0.153 \\
\hline
\end{tabular}

Table 3. Body weight gain (g) in subsequent weeks of duck growth $(\overline{\mathrm{x}})(\mathrm{N}=102$ ducks per group). $A$ ducks fed an SBM-based diet; $B$ ducks fed a diet based on yellow lupin and rapeseed meal. ${ }^{\mathrm{a}, \mathrm{b}}$ Means in rows marked with different letters differ significantly $(P \leq 0.05)$. ${ }^{x}$ Significant group: sex interaction $(P \leq 0.05)$.

\begin{tabular}{|c|c|c|c|c|c|c|c|c|}
\hline \multirow[b]{2}{*}{ Parameter } & \multicolumn{2}{|l|}{ Group } & \multirow[b]{2}{*}{ SD } & \multicolumn{2}{|l|}{ Sex } & \multicolumn{3}{|l|}{$P$ value } \\
\hline & $\mathbf{A}$ & B & & Males & Females & Group & Sex & Interaction \\
\hline Body length $(\mathrm{cm})$ & 40.55 & 40.55 & 1.54 & $42.30^{\mathrm{a}}$ & $38.80^{\mathrm{b}}$ & 0.085 & 0.000 & 1.000 \\
\hline Abdomen length $(\mathrm{cm})$ & 23.55 & 23.45 & 1.16 & 24.00 & 23.00 & 0.854 & 0.081 & 0.584 \\
\hline Sternum length $(\mathrm{cm})$ & 17.50 & 17.20 & 0.75 & 17.15 & 17.55 & 0.384 & 0.250 & 0.250 \\
\hline Shank length $(\mathrm{cm})$ & 5.27 & 5.25 & 0.42 & 5.24 & 5.28 & 0.920 & 0.842 & 0.205 \\
\hline Wing length $(\mathrm{cm})$ & 10.50 & 10.30 & 0.27 & $10.80^{\mathrm{a}}$ & $10.00^{\mathrm{b}}$ & 0.177 & 0.000 & 0.121 \\
\hline Chest circumference $(\mathrm{cm})$ & 35.60 & 34.95 & 1.39 & 35.45 & 35.10 & 0.059 & 0.291 & $0.032^{x}$ \\
\hline Massiveness index (\%) & 13.41 & 14.00 & 0.74 & 13.59 & 13.89 & 0.070 & 0.391 & $0.002^{x}$ \\
\hline Compactness index (\%) & 151.64 & 149.34 & 7.74 & $146.49^{b}$ & $154.50^{\mathrm{a}}$ & 0.533 & 0.041 & 0.800 \\
\hline Long-leggedness index (\%) & 13.06 & 12.98 & 1.26 & $12.41^{\mathrm{b}}$ & $13.36^{\mathrm{a}}$ & 0.889 & 0.050 & 0.763 \\
\hline
\end{tabular}

Table 4. Zoometric traits $(\mathrm{cm})$ and body conformation indices $(\%)$ of ducks $(\overline{\mathrm{x}} \pm \mathrm{SD})(\mathrm{N}=10$ ducks per group). $A$ ducks fed an SBM-based diet; $B$ ducks fed a diet based on yellow lupin and rapeseed meal. ${ }^{\mathrm{a}, \mathrm{b}}$ Means in rows marked with different letters differ significantly $(P \leq 0.05)$. ${ }^{x}$ Significant group: sex interaction $(P \leq 0.05)$.

Carcass traits and physicochemical properties of meat. Live body weight of ducks selected for slaughter was significantly higher in group A than in group B, and higher in males than in females. Differences were significant at $P=0.000$ for both analysed variables. There were significant differences in the chilled carcass weight between dietary treatment groups (higher carcass weight in group $A$ than in $B, P=0.000$ ). Dressing percentage was significantly lower in males than in females $(P=0.008)$. The weight of breast muscles and wings was significantly higher in group A fed an SBM-based diet $(P<0.05)$. The proportion of skin with subcutaneous fat in carcass was significantly higher in group B compared to group A $(P=0.028)$. Significant sex-related differences were found for the weight of skin with subcutaneous fat, abdominal fat, weight of stomach and liver, and the pro- 


\begin{tabular}{|c|c|c|c|c|c|c|c|c|c|}
\hline \multirow{2}{*}{\multicolumn{2}{|c|}{ Parameter }} & \multicolumn{2}{|l|}{ Group } & \multirow[b]{2}{*}{$\mathbf{V}(\%)$} & \multicolumn{2}{|l|}{ Sex } & \multicolumn{3}{|l|}{$P$ value } \\
\hline & & \multirow[t]{2}{*}{$\mathbf{A}$} & \multirow[t]{2}{*}{ B } & & \multirow[t]{2}{*}{ Males } & \multirow[t]{2}{*}{ Females } & \multirow[t]{2}{*}{ Group } & \multirow[t]{2}{*}{ Sex } & \multirow[t]{2}{*}{ Interaction } \\
\hline Weight & & & & & & & & & \\
\hline $\mathrm{g}$ & Body, before slaughter & $3,343.30^{\mathrm{a}}$ & $3,096.00^{\mathrm{b}}$ & 1.00 & $3,295.90^{\mathrm{a}}$ & $3,141.40^{\mathrm{b}}$ & 0.000 & 0.000 & $0.000^{x}$ \\
\hline g & Chilled carcass & $2,312 \cdot 10^{\mathrm{a}}$ & $2,144.63^{\mathrm{b}}$ & 2.99 & $2,237.61$ & $2,219.12$ & 0.000 & 0.580 & 0.723 \\
\hline$\%$ & Dressing percentage & 69.90 & 70.12 & 3.00 & $68.55^{\mathrm{b}}$ & $71.48^{\mathrm{a}}$ & 0.822 & 0.008 & 0.320 \\
\hline \multicolumn{10}{|c|}{$\begin{array}{l}\text { Weight and propor- } \\
\text { tion in carcass }\end{array}$} \\
\hline $\mathrm{g}$ & \multirow{2}{*}{ Breast muscles } & $452.67^{\mathrm{a}}$ & $388.45^{\mathrm{b}}$ & 10.26 & 412.30 & 428.82 & 0.004 & 0.402 & 0.633 \\
\hline$\%$ & & 19.59 & 18.11 & 9.68 & 18.38 & 19.31 & 0.090 & 0.275 & 0.680 \\
\hline $\mathrm{g}$ & \multirow{2}{*}{ Leg muscles } & 295.18 & 284.02 & 6.55 & 297.82 & 281.38 & 0.217 & 0.077 & 0.342 \\
\hline$\%$ & & 12.76 & 13.24 & 5.37 & 13.31 & 12.69 & 0.143 & 0.070 & 0.365 \\
\hline $\mathrm{g}$ & \multirow{2}{*}{ Wings } & $276.23^{\mathrm{a}}$ & $262.57^{\mathrm{b}}$ & 5.06 & 275.22 & 263.58 & 0.045 & 0.082 & 0.271 \\
\hline$\%$ & & 11.96 & 12.25 & 5.84 & 12.32 & 11.89 & 0.402 & 0.226 & 0.501 \\
\hline g & \multirow{2}{*}{$\begin{array}{l}\text { Skin with subcutane- } \\
\text { ous fat }\end{array}$} & 382.84 & 397.88 & 10.43 & $366.74^{\mathrm{b}}$ & $413.98^{\mathrm{a}}$ & 0.430 & 0.022 & 0.890 \\
\hline$\%$ & & $16.58^{\mathrm{b}}$ & $18.55^{\mathrm{a}}$ & 10.21 & $16.42^{\mathrm{b}}$ & $18.71^{\mathrm{a}}$ & 0.028 & 0.013 & 0.891 \\
\hline $\mathrm{g}$ & \multirow{2}{*}{ Abdominal fat } & 24.04 & 25.84 & 21.24 & $21.55^{\mathrm{b}}$ & $28.33^{a}$ & 0.485 & 0.016 & 0.919 \\
\hline$\%$ & & 1.00 & 1.21 & 24.30 & $0.92^{\mathrm{b}}$ & $1.28^{\mathrm{a}}$ & 0.120 & 0.011 & 0.857 \\
\hline $\mathrm{g}$ & \multirow{2}{*}{ Skin with neck } & 117.62 & 103.29 & 14.59 & 115.45 & 105.46 & 0.065 & 0.186 & 0.109 \\
\hline$\%$ & & 5.09 & 4.82 & 14.62 & 5.17 & 4.73 & 0.413 & 0.197 & 0.088 \\
\hline $\mathrm{g}$ & \multirow{2}{*}{ Neck } & 160.87 & 160.51 & 7.16 & 166.14 & 155.24 & 0.950 & 0.074 & 0.343 \\
\hline$\%$ & & 7.40 & 7.49 & 9.80 & $7.88^{\mathrm{a}}$ & $7.01^{\mathrm{b}}$ & 0.820 & 0.043 & 0.772 \\
\hline $\mathrm{g}$ & \multirow{2}{*}{ Carcass remains } & 558.52 & 509.72 & 9.68 & 558.10 & 510.14 & 0.052 & 0.055 & 0.519 \\
\hline$\%$ & & 24.16 & 23.76 & 9.37 & 24.93 & 23.00 & 0.704 & 0.080 & 0.668 \\
\hline $\mathrm{g}$ & \begin{tabular}{|l|} 
Stomach \\
\end{tabular} & 105.78 & 100.85 & 9.65 & $110.17^{\mathrm{a}}$ & $96.46^{\mathrm{b}}$ & 0.306 & 0.010 & 0.744 \\
\hline $\mathrm{g}$ & Liver & 71.95 & 75.55 & 13.08 & $80.70^{\mathrm{a}}$ & $66.80^{\mathrm{b}}$ & 0.421 & 0.006 & 0.214 \\
\hline $\mathrm{g}$ & Heart & 17.61 & 16.74 & 9.03 & 17.64 & 16.71 & 0.259 & 0.232 & 0.326 \\
\hline
\end{tabular}

Table 5. Means and coefficients of variation (\%) for body weight and carcass weight, dressing percentage and weight of carcass elements and percentage share of cuts in carcasses $(\overline{\mathrm{x}}, \mathrm{V})(\mathrm{N}=10$ ducks per group). $A$ ducks fed an SBM-based diet; $B$ ducks fed a diet based on yellow lupin and rapeseed meal. ${ }^{\mathrm{a}, \mathrm{b}}$ Means in rows marked with different letters differ significantly $(P \leq 0.05)$. ${ }^{x}$ Significant group: sex interaction $(P \leq 0.05)$.

portion of skin with subcutaneous fat, abdominal fat and the proportion of neck in the carcass; all these parameters except weight of stomach and liver were higher in females $(P<0.05)$. No significant differences were found between other variables $(P>0.05)$. There was no significant interaction between variables: treatment group and sex $(P>0.05)$, except for live body weight of ducks $(P=0.000)$ (Table 5). Better cooking loss of breast muscles was found in birds from group B fed a diet based on yellow lupin compared to group A $(P=0.026)$. Other physicochemical parameters did not differ significantly between groups for both variables $(P>0.05)$. No interaction effect was found between treatment group and sex $(P>0.05)$ (Table 6). Higher content of linolenic acid (C18:3 n-3) and higher content of eicosenoic acid (C20:1 n-9) in subcutaneous fat in group B compared to control ducks fed the SBM-based diet was found. The percentage of $n-3$ fatty acids (C18:n-3) was significantly higher in group B compared to group A, but the ratio PUFA n-6/n-3 was significantly lower $(P=0.000)$. Fatty acid composition was also analysed in relation to sex. The content of pentadecanoic $(\mathrm{C} 15: 0)$, palmitoleic $(\mathrm{C} 16: 1)$, heptadecanoic (C17:0), linoleic acid (C18:2 n-6), and polyunsaturated acids (PUFA), including omega-6 and hypocholesterolemic FA (DFA), as well as PUFA/SFA and DFA/OFA (hypercholesterolemic fatty acids) were significantly higher in males than in females $(P<0.05)$ (Table 7$)$. No interaction effect between variables was found $(P>0.05)$. The content of specific fatty acids was also lower in abdominal fat from control group A compared to group B. There were significant differences in the content of linolenic acid (C18:3 n-3), eicosenoic acid (C20:1 n-9) and docosanoic acid (C22:0), and abdominal fat from group A was characterised by a lower content of n-3 acids, but a higher $n-6 / n-3$ ratio $(P<0.05)$. There were also differences in fatty acid composition, including higher content of heptadecanoic (C17:0), linoleic (C18:2 n-6), docosanoic (C22:0) acids, total PUFA, and the PUFA/SFA ratio in males than in females. The content of palmitoleic acid $(\mathrm{C} 16: 1)$ was higher in females $(P=0.045)$ (Table 8$)$. No interaction effect between the diet-sex was found $(P>0.05)$.

\section{Discussion}

Growth performance. In our study the European broiler index (EBI) for ducks ranged from 156.02 (B) to

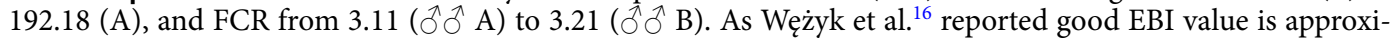
mately 190. Total feed intake over the 8-week rearing period was approx. $10 \mathrm{~kg}$. Feed intake in control and treatment groups was comparable. Zduńczyk et al. ${ }^{17}$ reported that the inclusion of yellow lupin seeds $\left(\mathrm{LL}_{8,16}\right.$ and 24$)$ in the diet of turkeys had no negative effect on feed intake. Hejdysz et al. ${ }^{18}$ also demonstrated no significant effect 


\begin{tabular}{|c|c|c|c|c|c|c|c|c|c|}
\hline \multirow[b]{2}{*}{ Parameter } & \multirow[b]{2}{*}{ Element } & \multicolumn{2}{|c|}{ Group } & \multirow[b]{2}{*}{ SD } & \multicolumn{2}{|l|}{ Sex } & \multicolumn{3}{|l|}{$P$ value } \\
\hline & & $\mathbf{A}$ & B & & Males & Females & Group & Sex & Interaction \\
\hline $\mathrm{pH}_{24}$ & Breast & 5.83 & 5.82 & 0.06 & 5.81 & 5.84 & 0.670 & 0.347 & 0.768 \\
\hline \multirow{2}{*}{ Water-holding capacity (\%) } & Breast & 58.05 & 60.32 & 9.87 & 60.94 & 58.01 & 0.165 & 0.104 & 0.056 \\
\hline & Legs & 64.78 & 62.82 & 7.71 & 62.93 & 64.65 & 0.122 & 0.177 & 0.318 \\
\hline \multirow{2}{*}{ Drip loss (\%) } & Breast & 1.47 & 1.37 & 0.45 & 1.39 & 1.45 & 0.643 & 0.780 & 0.762 \\
\hline & Legs & 1.26 & 0.71 & 0.68 & 0.90 & 1.08 & 0.106 & 0.588 & 0.812 \\
\hline \multirow{2}{*}{ Cooking loss (\%) } & Breast & $25.12^{\mathrm{a}}$ & $22.22^{\mathrm{b}}$ & 2.33 & 24.66 & 22.68 & 0.026 & 0.114 & 0.709 \\
\hline & Legs & 24.01 & 25.00 & 2.82 & 24.45 & 24.63 & 0.485 & 0.893 & 0.289 \\
\hline \multirow{3}{*}{$\mathrm{L}^{*}$ - colour lightness } & Skin & 65.87 & 65.22 & 2.21 & 65.56 & 65.53 & 0.554 & 0.973 & 0.326 \\
\hline & Breast muscles & 33.99 & 34.98 & 1.72 & 34.70 & 34.26 & 0.227 & 0.587 & 0.652 \\
\hline & Leg muscles & 35.10 & 37.30 & 2.92 & 36.12 & 36.28 & 0.123 & 0.907 & 0.552 \\
\hline \multirow{3}{*}{$\mathrm{a}^{*}$-colour redness } & Skin & 4.66 & 4.57 & 1.21 & 4.32 & 4.91 & 0.867 & 0.299 & 0.102 \\
\hline & Breast muscles & 14.60 & 14.58 & 1.03 & 14.87 & 14.31 & 0.972 & 0.281 & 0.244 \\
\hline & Leg muscles & 13.76 & 13.80 & 1.44 & 14.35 & 13.20 & 0.952 & 0.110 & 0.417 \\
\hline \multirow{3}{*}{$\mathrm{b}^{*}$-colour yellowness } & Skin & 12.57 & 13.68 & 2.04 & 13.28 & 12.97 & 0.244 & 0.734 & 0.397 \\
\hline & \begin{tabular}{|l} 
Breast muscles \\
\end{tabular} & 2.06 & 1.43 & 1.61 & 1.85 & 1.63 & 0.341 & 0.740 & 0.950 \\
\hline & Leg muscles & 3.45 & 4.19 & 1.35 & 3.97 & 3.66 & 0.265 & 0.634 & 0.441 \\
\hline
\end{tabular}

Table 6. Physicochemical parameters of breast and leg muscles from ducks ( $\mathrm{N}=10$ ducks per group). $A$ ducks fed an SBM-based diet; $B$ ducks fed a diet based on yellow lupin and rapeseed meal. ${ }^{a . b}$ Means in rows marked with different letters differ significantly $(P \leq 0.05)$.

of narrow-leaved lupin and type of processed seeds on feed intake and FCR in broiler chicken. In our study the mortality rate of ducks was from $1.56 \%(\hat{\partial} \mathrm{A})$ to $7.81 \%(\hat{\partial} \mathrm{B})$. Presumably, diet was one of the main factors determining the survival of birds. In our study the body weight and weekly body weight gains were lower in ducks from the treatment group compared to control birds $(P \leq 0.05)$. Kuźniacka et al. ${ }^{19}$ reported that the final body weight of ducks fed diets with the inclusion of lupin seeds was comparable to the body weight of ducks fed a balanced SBM-based feed. Biesiada-Drzazga et al. ${ }^{20}$ found higher body weight and growth rate in Pekin ducks $\left(\partial^{1}+\right.$ ) at 14 and 28 days-old, but lower at 49 days-old compared to the body weight of ducks measured in our study. Mierlita and Popovici ${ }^{21}$ reported from their experimental study on Ross 308 broiler chickens the significantly highest body weight in 21-day-old birds fed a standard SBM-based diet and the lowest in the $\mathrm{LA}_{40}$ group. However, the body weight of 35-day-old broiler chickens was comparable. A 40 and $60 \%$ inclusion of lupin flour per feed ration had no adverse effect on the body weight of birds measured at the end of the rearing period (day 42). Daily feed intake in control and treatment groups was comparable. Suchỳ et al. ${ }^{22}$ also found no significant differences between the body weight of Ross 308 broiler chickens fed white lupin (LA) seeds LA 6.66-31.03 $_{\text {meas- }}$ ured on days 15, 30 and 42 of rearing. In week 2 of life, the highest body weight gain was found in ducks from the control group A (104.39\%) and treatment group B (95.37\%). The values of body conformation indices, sternum crest length and chest circumference were higher in female ducks. Experiments conducted by Kokoszyński and Bernacki ${ }^{23}$ conducted on P44 and P55 ducks revealed lower values compared to those found in our study.

Carcass traits and physicochemical properties of meat. Body weight and carcass weight were significantly higher in control ducks than in ducks from the treatment group. The analysis of carcass quality revealed significant differences in the weight of breast muscles and wings, as well as the proportion of wings in gutted carcass with neck. Kuźniacka et al. ${ }^{19}$ reported a slightly higher dressing percentage in ducks fed a balanced feed based on narrow lupin seeds compared to ducks fed mixtures with the inclusion of soybean meal. An experimental study by Witak et al. ${ }^{24}$ revealed that the inclusion of yellow lupin seeds in the diet of A44 ducks (2.5, 5 and 10\% in weeks 1 to 3 of life, and 7.5, 10 and 15\% from week 4 of rearing to slaughter) had no effect on the weight of gutted carcass with neck $(\mathrm{g})$ and the weight and proportion of skin with subcutaneous fat, abdominal fat, breast muscles and leg muscles, or carcass remains. Witak et al. ${ }^{24}$ reported a negative $(P \leq 0.05)$ effect of a $10 \%$ inclusion of lupin seeds on the dressing percentage of ducks compared to the control group and other treatment groups. There were also significant sex-related differences in the dressing percentage and the proportion of subcutaneous fat in carcass, which were higher in female ducks, similar to our study. Only the weight of carcass remains was higher in male ducks. The proportion of individual elements of carcass reported by Witak et al. ${ }^{24}$ was slightly higher than in our study. In the study by Suchỳ et al. ${ }^{22}$ carcass weight and the weight and proportion of breast muscles in carcass was significantly lower in Ross 308 broiler chickens fed a diet with the inclusion of white lupin seeds (LA) compared to the control group (SBM), but the dressing percentage of birds was comparable $(70.99 \%$ in the control group vs. $73.69 \%$ in treatment groups). Diet also had no negative effect on the weight and proportion of neck and legs in carcass. Comparable results were found in our study. Our study found no significant effect of the source of protein in the diet on the weight of carcass elements, but the weight of stomach and liver was significantly higher in males compared to females. In our study the proportion of wings in the total weight of carcass was between $11.89 \%$ for female ducks and $12.32 \%$ for male ducks. Similar data on the weight of duck wings were reported by Kokoszyński et al. ${ }^{25}$. 


\begin{tabular}{|c|c|c|c|c|c|c|c|c|}
\hline \multirow[b]{2}{*}{ Fatty acids } & \multicolumn{2}{|l|}{\begin{tabular}{|l|} 
Group \\
\end{tabular}} & \multirow[b]{2}{*}{ SD } & \multicolumn{2}{|l|}{ Sex } & \multicolumn{3}{|l|}{$P$ value } \\
\hline & A & B & & Males & Females & Group & Sex & Interaction \\
\hline C14:0 & 1.10 & 1.07 & 0.10 & 1.08 & 1.09 & 0.434 & 0.946 & 0.339 \\
\hline C15:0 & 0.11 & 0.12 & 0.02 & $0.12^{\mathrm{a}}$ & $0.11^{\mathrm{b}}$ & 0.064 & 0.018 & 0.335 \\
\hline C16:0 & 47.06 & 46.34 & 1.29 & 46.10 & 47.25 & 0.206 & 0.059 & 0.887 \\
\hline C16:1 & 2.09 & 2.19 & 0.31 & $1.98^{\mathrm{b}}$ & $2.31^{\mathrm{a}}$ & 0.432 & 0.016 & 0.879 \\
\hline C17:0 & 0.14 & 0.16 & 0.03 & $0.16^{\mathrm{a}}$ & $0.13^{\mathrm{b}}$ & 0.086 & 0.006 & 0.925 \\
\hline C18:0 & 11.09 & 10.90 & 1.38 & 11.30 & 10.69 & 0.767 & 0.359 & 0.741 \\
\hline C18:1 n-9 & 29.51 & 29.82 & 2.24 & 29.53 & 29.79 & 0.784 & 0.817 & 0.736 \\
\hline C18:2 n-6 & 8.02 & 8.36 & 0.81 & $8.66^{\mathrm{a}}$ & $7.72^{\mathrm{b}}$ & 0.270 & 0.007 & 0.201 \\
\hline C18:3 n-3 & $0.60^{\mathrm{b}}$ & $0.70^{\mathrm{a}}$ & 0.08 & 0.69 & 0.62 & 0.006 & 0.059 & 0.284 \\
\hline C20:1 n-9 & $0.19^{\mathrm{b}}$ & $0.22^{\mathrm{a}}$ & 0.02 & 0.21 & 0.20 & 0.002 & 0.498 & 0.369 \\
\hline C22:0 & $0.09^{\mathrm{b}}$ & $0.13^{\mathrm{a}}$ & 0.03 & 0.12 & 0.10 & 0.011 & 0.053 & 0.939 \\
\hline SFA & 59.59 & 58.71 & 2.07 & 58.93 & 59.36 & 0.382 & 0.667 & 0.928 \\
\hline UFA & 40.41 & 41.30 & 2.07 & 41.07 & 40.64 & 0.379 & 0.668 & 0.927 \\
\hline MUFA & 31.79 & 32.23 & 2.33 & 31.72 & 32.30 & 0.715 & 0.628 & 0.770 \\
\hline PUFA & 8.62 & 9.07 & 0.68 & $9.35^{\mathrm{a}}$ & $8.34^{\mathrm{b}}$ & 0.195 & 0.008 & 0.202 \\
\hline $\mathrm{n}-3$ & $0.60^{\mathrm{b}}$ & $0.70^{\mathrm{a}}$ & 0.07 & 0.69 & 0.62 & 0.006 & 0.059 & 0.284 \\
\hline$n-6$ & 8.02 & 8.36 & 0.62 & $8.66^{\mathrm{a}}$ & $7.72^{\mathrm{b}}$ & 0.270 & 0.007 & 0.201 \\
\hline $\mathrm{n}-9$ & 29.70 & 30.04 & 2.19 & 29.74 & 30.00 & 0.763 & 0.822 & 0.743 \\
\hline DFA & 49.41 & 50.00 & 1.28 & $50.39^{a}$ & $49.02^{\mathrm{b}}$ & 0.328 & 0.034 & 0.810 \\
\hline OFA & 48.16 & 47.40 & 1.26 & 47.23 & 48.34 & 0.205 & 0.069 & 0.834 \\
\hline UFA/SFA & 0.68 & 0.70 & 0.06 & 0.54 & 0.55 & 0.397 & 0.630 & 0.887 \\
\hline MUFA/SFA & 0.54 & 0.55 & 0.06 & 0.54 & 0.55 & 0.628 & 0.869 & 0.910 \\
\hline PUFA/SFA & 0.14 & 0.15 & 0.01 & $0.16^{\mathrm{a}}$ & $0.14^{\mathrm{b}}$ & 0.055 & 0.002 & 0.158 \\
\hline DFA/SFA & 0.83 & 0.85 & 0.05 & 0.86 & 0.83 & 0.330 & 0.181 & 0.986 \\
\hline DFA/OFA & 1.03 & 1.06 & 0.05 & $1.07^{\mathrm{a}}$ & $1.02^{\mathrm{b}}$ & 0.251 & 0.047 & 0.817 \\
\hline$n-6 / n-3$ & $13.35^{\mathrm{a}}$ & $11.96^{\mathrm{b}}$ & 0.43 & 12.72 & 12.59 & 0.000 & 0.691 & 0.728 \\
\hline$n-9 / n-6$ & 3.78 & 3.61 & 0.41 & 3.48 & 3.91 & 0.476 & 0.069 & 0.405 \\
\hline$n-9 / n-3$ & 50.39 & 43.37 & 6.79 & 44.21 & 49.55 & 0.058 & 0.140 & 0.391 \\
\hline
\end{tabular}

Table 7. Fatty acid composition (\% of total fatty acids) in subcutaneous fat from ducks $(\overline{\mathrm{x}} \pm \mathrm{SD})(\mathrm{N}=10$ ducks per group). $A$ ducks fed an SBM-based diet; $B$ ducks fed a diet based on yellow lupin and rapeseed meal. DFA hypocholesterolemic fatty acids, OFA hypercholesterolemic fatty acids, UFA unsaturated fatty acids, SFA saturated fatty acids, MUFA monounsaturated fatty acids, PUFA polyunsaturated fatty acids. ${ }^{\mathrm{a}, \mathrm{b}}$ Means in rows marked with different letters differ significantly $(P \leq 0.05)$.

In our study, dietary treatments had no significant effect on the colour of duck breast and leg muscles. Our findings were different from those reported by other researchers ${ }^{26-28}$. Other studies ${ }^{29}$ found that muscles from turkeys fed $\mathrm{LL}_{16}$ and $\mathrm{LL}_{24}$ diets were characterised by a significantly greater yellowness $\left(\mathrm{b}^{*}\right)$ compared to control birds. An experimental study by Witak et al. ${ }^{24}$ found no significant differences in the colour of breast and leg muscles between the control ducks receiving a feed mixture with the addition of SBM, and treatment groups $\left(\mathrm{LL}_{2.5-15}\right)$ or between males and females, which is consistent with our results.

Moreover, Witak et al. ${ }^{24}$ reported that the source of plant protein did not influence the water-holding capacity of breast and leg muscles from broiler ducks. The sex of birds was the only variable with a significant impact on the water-holding capacity of breast muscles and was higher in female than in male birds. On the other hand, Kuźniacka et al. ${ }^{19}$ reported higher water-holding capacity of breast and leg muscles from ducks fed a diet with the inclusion of lupin seeds compared to birds receiving a feed mixture with SBM. Wu et al. ${ }^{30}$ reported that in Cherry Valley ducks cooking loss was $38.10 \%$, and drip loss was $7.48 \%$. In our study we found no relationship between the sex of ducks or their diet and the $\mathrm{pH}$ of breast muscles, which according to literature data is in the range of 5.65-6.20 and depends on the level of glycogen reserves in muscles ${ }^{27,31,32}$. The value of $\mathrm{pH}$ decreases post-mortem due to the increased concentration of lactic acid in muscles, and this process determines meat quality. The rapid drop in $\mathrm{pH}$ may result in meat paleness, reduced water-holding capacity and an excessively soft structure of meat ${ }^{33}$. In our experiments the post-mortem drop in the $\mathrm{pH}$ of breast muscles was normal, which indicates normal metabolic changes in muscles ${ }^{28}$. Krawczyk et al. ${ }^{29}$ did not observe any significant differences in the $\mathrm{pH}$ of turkey meat measured $24 \mathrm{~h}$ post-mortem between the control group (SBM) and treatment groups $\left(\mathrm{LL}_{8-24}\right)$. The $\mathrm{pH}_{24}$ of breast muscles from ducks measured in our study was higher than 5.8. Witak et al. ${ }^{24}$ reported slightly lower $\mathrm{pH}$ values for breast muscles (5.74 to 5.78) from ducks on an LL diet compared to our findings. Wu et al. ${ }^{30}$ reported that the $\mathrm{pH}$ of muscles from Cherry Valley ducks was in the range of $5.97\left(\mathrm{pH}_{45} \mathrm{~min}\right)$ to 5.77 $\left(\mathrm{pH}_{24 \mathrm{~h}}\right)$. The water-holding capacity of duck muscles was comparable between groups and sexes of birds. 


\begin{tabular}{|c|c|c|c|c|c|c|c|c|}
\hline \multirow[b]{2}{*}{ Fatty acids } & \multicolumn{2}{|l|}{ Group } & \multirow[b]{2}{*}{ SD } & \multicolumn{2}{|l|}{ Sex } & \multicolumn{3}{|l|}{$P$ value } \\
\hline & A & B & & Males & Females & Group & Sex & Interaction \\
\hline C14:0 & 1.15 & 1.10 & 0.10 & 1.12 & 1.13 & 0.318 & 0.704 & 0.231 \\
\hline C15:0 & 0.11 & 0.12 & 0.02 & 0.13 & 0.11 & 0.226 & 0.051 & 0.461 \\
\hline C16:0 & 46.20 & 46.17 & 1.19 & 45.64 & 46.68 & 0.889 & 0.065 & 0.756 \\
\hline C16:1 & 1.95 & 2.04 & 0.33 & $1.82^{\mathrm{b}}$ & $2.14^{\mathrm{a}}$ & 0.593 & 0.045 & 0.835 \\
\hline C17:0 & 0.15 & 0.16 & 0.03 & $0.17^{\mathrm{a}}$ & $0.14^{\mathrm{b}}$ & 0.294 & 0.014 & 0.548 \\
\hline C18:0 & 12.38 & 11.54 & 1.39 & 12.26 & 11.73 & 0.278 & 0.545 & 0.678 \\
\hline C18:1 n-9 & 28.87 & 29.40 & 2.36 & 29.03 & 29.20 & \begin{tabular}{|l|}
0.649 \\
\end{tabular} & 0.935 & 0.578 \\
\hline $\mathrm{C} 18: 2 \mathrm{n}-6$ & 8.33 & 8.46 & \begin{tabular}{|l|}
0.74 \\
\end{tabular} & $8.86^{\mathrm{a}}$ & $7.97^{\mathrm{b}}$ & 0.593 & 0.007 & 0.128 \\
\hline C18:3 n-3 & $0.59^{\mathrm{b}}$ & $0.67^{\mathrm{a}}$ & \begin{tabular}{|l|}
0.07 \\
\end{tabular} & 0.65 & 0.61 & 0.025 & \begin{tabular}{|l|}
0.187 \\
\end{tabular} & 0.137 \\
\hline C20:1 n-9 & $0.20^{\mathrm{b}}$ & $0.23^{\mathrm{a}}$ & 0.02 & 0.22 & 0.21 & 0.000 & 0.099 & 0.841 \\
\hline C22:0 & $0.08^{\mathrm{b}}$ & $0.11^{\mathrm{a}}$ & 0.04 & $0.11^{\mathrm{a}}$ & $0.08^{\mathrm{b}}$ & 0.024 & 0.043 & 0.680 \\
\hline SFA & 60.07 & 59.21 & 2.04 & 59.42 & 59.88 & 0.453 & 0.658 & 0.843 \\
\hline UFA & 39.93 & 40.80 & 2.05 & 40.58 & 40.13 & 0.452 & 0.661 & 0.844 \\
\hline MUFA & 31.08 & 31.78 & 2.38 & 31.18 & 31.63 & 0.606 & 0.758 & 0.597 \\
\hline PUFA & 8.92 & 9.12 & 0.60 & $9.51^{\mathrm{a}}$ & $8.57^{\mathrm{b}}$ & 0.513 & 0.007 & 0.121 \\
\hline$n-3$ & $0.59^{\mathrm{b}}$ & $0.67^{\mathrm{a}}$ & 0.06 & 0.65 & 0.61 & 0.024 & 0.160 & 0.137 \\
\hline$n-6$ & 8.33 & 8.46 & \begin{tabular}{|l|}
0.57 \\
\end{tabular} & $8.86^{\mathrm{a}}$ & $7.97^{\mathrm{b}}$ & 0.649 & 0.006 & 0.128 \\
\hline$n-9$ & 29.06 & 29.63 & 2.22 & 29.25 & 29.41 & 0.647 & 0.916 & 0.580 \\
\hline DFA & 52.31 & 52.33 & 1.17 & 52.83 & 51.86 & 0.969 & 0.101 & 0.877 \\
\hline OFA & 47.35 & 47.28 & 1.15 & 46.76 & 47.81 & 0.901 & 0.072 & 0.850 \\
\hline UFA/SFA & 0.67 & 0.69 & 0.06 & 0.69 & 0.67 & 0.473 & 0.570 & 0.899 \\
\hline MUFA/SFA & 0.52 & 0.54 & 0.06 & 0.53 & 0.53 & 0.583 & 0.983 & 0.715 \\
\hline PUFA/SFA & 0.15 & 0.15 & 0.01 & $0.16^{\mathrm{a}}$ & $0.14^{\mathrm{b}}$ & 0.191 & 0.000 & 0.083 \\
\hline DFA/SFA & 0.87 & 0.88 & 0.05 & 0.89 & 0.87 & 0.639 & \begin{tabular}{|l|}
0.287 \\
\end{tabular} & 0.997 \\
\hline DFA/OFA & 1.11 & 1.11 & 0.05 & 1.13 & 1.09 & 0.942 & 0.078 & 0.846 \\
\hline$n-6 / 3$ & $14.08^{\mathrm{a}}$ & $12.75^{\mathrm{b}}$ & 0.73 & 13.76 & 13.17 & 0.004 & 0.174 & 0.510 \\
\hline$n-9 / 6$ & 3.55 & 3.52 & 0.43 & 3.34 & 3.71 & 0.911 & 0.118 & 0.295 \\
\hline$n-9 / 3$ & 49.76 & 44.95 & 6.49 & 45.78 & \begin{tabular}{|l}
49.02 \\
\end{tabular} & 0.157 & 0.293 & 0.174 \\
\hline
\end{tabular}

Table 8. Fatty acid composition (\% of total fatty acids) in abdominal fat from ducks ( $\bar{x} \pm S D)(N=10$ ducks per group). $A$ ducks fed an SBM-based diet; $B$ ducks fed a diet based on yellow lupin and rapeseed meal. DFA hypocholesterolemic fatty acids, OFA hypercholesterolemic fatty acids, UFA unsaturated fatty acids, SFA saturated fatty acids, MUFA monounsaturated fatty acids, PUFA polyunsaturated fatty acids; n-3 OMEGA 3, n-6 OMEGA 6, n-9 OMEGA 9. ${ }^{\mathrm{a}}{ }^{\mathrm{b}}$ Means in rows marked with different letters differ significantly $(P \leq 0.05)$.

Lipid content and fatty acid composition of tissues. Fat from lupin seeds is characterised by a high content of unsaturated fatty acids, especially linoleic acid (C18:2 n-6) ${ }^{34}$. Mieczkowska and Smulikowska ${ }^{35}$ reported that the dietary inclusion of lupin seeds influenced the level of oleic acid (C18:1 n-9) and a-linolenic acid (C18:3 n-3) in fat from broilers. Diet has a modifying effect on fatty acid composition in somatic lipids, and this improves the nutritional properties of poultry meat. Results of the cited studies correspond with our findings, since we measured significantly higher content of $\alpha$-linolenic acid in subcutaneous and abdominal fat from ducks on a diet with the inclusion of lupin seeds. Biesiada-Drzazga ${ }^{31}$ indicated that the partial replacement of soybean meal with lupin seed meal and rapeseed meal in the diet of White Kołuda geese reared for 10 weeks had a positive effect and was associated with a $2.2 \%$ reduction in the total content of SFA, and a $2.85 \%$ increase in the total content of MUFA. On the other hand, a significantly lower content of SFA and higher content of UFA was found in skin with subcutaneous fat (by $1.7 \%$ on average) and in leg muscles (by 1.2 and $1.7 \%$, respectively) from geese receiving sunflower meal or lupin meal with sunflower meal ${ }^{32}$. Another study by Biesiada-Drzazga ${ }^{36}$ revealed no differences in fatty acid composition for breast muscle, leg muscles and skin with subcutaneous fat between geese fed soybean meal and geese fed a diet with an admixture of rapeseed meal. Skin with subcutaneous fat was characterised by a more beneficial fatty acid composition compared to abdominal fat (higher UFA/ SFA ratio), which corresponds with findings by Karpińska and Batura ${ }^{37}$. In oat geese, a dietary inclusion of sunflower seeds (5\% in weeks 0 to 3,9\% in weeks 4 to 8 and $14 \%$ in weeks 9 to 10 ) had a positive effect on the content of oleic acid (C18:1 n-9) in abdominal fat, subcutaneous fat and lipids from breast muscles, and on the content of palmitoleic acid (C16:1) in subcutaneous fat and breast muscles ${ }^{38}$. Feeding turkeys with a mixture based on yellow lupin seeds $\left(\mathrm{LL}_{8-24}\right)$ influenced fatty acid composition in breast muscles by reducing the level of saturated fatty acids (SFA), including palmitic (C16:0) and myristic acid (C14:0), and increasing the levels of polyunsaturated fatty acids (PUFA): linoleic (C18:2 n-6) and linolenic acid (C18:3 n-3) ${ }^{29}$. Experimental studies by Kiczorowska et al. ${ }^{39}$ revealed significantly higher levels of palmitoleic (C16:1) and arachidonic acid (C20:4 n-9), and a 


\begin{tabular}{|l|l|l|}
\hline Component (\%) & A & B \\
\hline Wheat & 9.00 & 17.50 \\
\hline Soybean meal (Hipro) & 57.90 & - \\
\hline Yellow lupin (Mister) & - & 60.10 \\
\hline Rapeseed meal & - & 14.00 \\
\hline Wheat bran & 25.00 & - \\
\hline Monocalcium phosphate & 2.70 & 2.90 \\
\hline Fodder chalk & 2.50 & 2.30 \\
\hline Fodder salt & 0.50 & 0.60 \\
\hline Sodium carbonate & 0.40 & 0.40 \\
\hline L-lysine/technically pure/ & - & 0.10 \\
\hline DL-methionine & 0.50 & 0.60 \\
\hline Premix grower 5\%, ${ }^{*}$ & 1.50 & 1.50 \\
\hline Calcium & 2.24 & 2.20 \\
\hline Available phosphorus & 0.58 & 0.58 \\
\hline Lysine & 1.90 & 1.90 \\
\hline Methionine & 0.90 & 0.90 \\
\hline Cysteine & 0.81 & 0.79 \\
\hline Threonine & 0.81 & 0.82 \\
\hline Tryptophane & 3.24 & 3.30 \\
\hline Nutritional value per kg of complete feed & & \\
\hline Metabolizable energy (MJ) & 11.41 & 11.41 \\
\hline Metabolizable energy (kcal) & $2,725.23$ & $2,725.23$ \\
\hline Crude protein (\%) & 17.30 & 17.30 \\
\hline & & \\
\hline & & \\
\hline
\end{tabular}

Table 9. Components of concentrates for ducks. ${ }^{\star}$ Vitamin-mineral premix provided per kg diet: Mn, $55 \mathrm{mg}$; $\mathrm{Zn}, 50 \mathrm{mg}$; Fe, $80 \mathrm{mg}$; Cu, $5 \mathrm{mg}$; Se, $0.1 \mathrm{mg}$; I, $0.36 \mathrm{mg}$; Na, 1.6 g, retinol, $2.48 \mathrm{mg}$; cholecalciferol $25 \mu \mathrm{g}$; DL-atocopherol, $60 \mathrm{mg}$; cyanocobalamin, $0.012 \mathrm{mg}$; menadione sodium bisulphite, $1.1 \mathrm{mg}$; niacin, $53 \mathrm{mg}$; choline chloride, 1,020 mg; folic acid, $0.75 \mathrm{mg}$; biotin, $0.25 \mathrm{mg}$; riboflavin, $5.5 \mathrm{mg}$.

significantly lower level of myristic acid (C14:0) in abdominal fat from broiler chickens fed with a 50\% inclusion of raw peas. This diet was also associated with increased content of palmitic (C16:0) and $\gamma$-linolenic acid (C18:3 $\mathrm{n}-6)$ in lipids from leg muscles compared to controls fed SBM.

In conclusion, yellow lupin in combination with rapeseed meal can be a source of protein in feed for broiler ducks, as shown by growth performance results and the dressing percentage of the carcass. Growth performance parameters and dressing percentage achieved for ducks fed this diet were comparable to those in birds on the balanced SBM-based diet. The use of balanced feeds with the inclusion of yellow lupin and rapeseed meal has a positive effect on fatty acid composition in abdominal and subcutaneous fat from broiler ducks. Meat from ducks fed this type of diet was characterized by a highest level of hypocholesterolemic and PUFA n-3. Feed with the inclusion of lupin seeds and rapeseed meal can be used in the diet of ducks at small poultry farms operating semi-intensive production, as indicated by the good quality of obtained meat. It is important for small farms, because not everybody has a possibility for own crops of soybean meal. In aspect of consumer market, nowadays is niche of non-GMO products, so it could give a wider choice for potential consumers.

\section{Materials and methods}

The research were done with recommendations of directive no. 2010/63/EU and resolution 13/2016 of the National Ethics Committee for Animal Experiments of June 17, 2016. The approval of Ethic Committee was not required. The slaughter of birds was carried out in accordance with the applicable rules on the handling of animals at the time of slaughter, including humane treatment. Also the methods used in the meat quality tests were carried out in accordance with the current and commonly used methods.

Animals and diets. The study was conducted on 204 Cherry Valley English Pekin ducks. Each duckling was weighted on Radwag PS 750/X scales, sexed, and marked with a jiffy wing band. Ducklings were reared in closed facilities under controlled environmental conditions (in accordance with Polish law, ducks were kept to a maximum of $10.5 \mathrm{~kg} / \mathrm{m}^{2}$ ). Air temperature was 27 to $31^{\circ} \mathrm{C}$ in week 1,23 to $29^{\circ} \mathrm{C}$ in week 2 , and 23 to $26^{\circ} \mathrm{C}$ in week 3 . The mean relative air humidity was $65 \%$. From the third week of life birds had access to outdoor pens. Birds were divided into two groups $(\mathrm{N}=102)$, each group was in five repetition, and subgroups depending on sex, with 51 males and 51 females in each subgroup. Control birds (A) received a mixture with concentrate containing soybean meal (SBM), and the treatment group (B) received a balanced feed with lupin seeds. The diet of ducks (A, B) was a mixture of $40 \%$ of concentrate and $60 \%$ of wheat from week 1 to 3 of life, and then $30 \%$ of concentrate and $70 \%$ of wheat from week 4 to 8 . The components of the concentrate and the nutritional value of feed mixture are presented in Table 9. The chemical composition of yellow lupin seeds, cv. Mister, is presented in 


\begin{tabular}{|c|c|c|}
\hline Parameter & Unit & Yellow lupin, cv. Mister \\
\hline Dry matter & $\%$ & 89.01 \\
\hline Crude ash & $\%$ & 4.15 \\
\hline Crude protein & $\%$ & 38.98 \\
\hline Crude fibre & $\%$ & 19.23 \\
\hline $\mathrm{ADF}$ & $\%$ & 24.24 \\
\hline NDF & $\%$ & 28.24 \\
\hline Crude fat & $\%$ & 5.26 \\
\hline Starch & $\%$ & - \\
\hline \multirow{2}{*}{ Energy } & $\mathrm{MJ} / \mathrm{kg}$ & 20.49 \\
\hline & $\mathrm{kcal} / \mathrm{kg}$ & $4,893.95$ \\
\hline Viscose & $\mathrm{cP}$ & 1.09 \\
\hline Asp & $\%$ & 8.81 \\
\hline Thr & $\%$ & 3.17 \\
\hline Ser & $\%$ & 4.24 \\
\hline Glut & $\%$ & 24.46 \\
\hline Pro & $\%$ & 6.08 \\
\hline Gly & $\%$ & 3.47 \\
\hline Ala & $\%$ & 2.83 \\
\hline Val & $\%$ & 3.17 \\
\hline Iso & $\%$ & 3.20 \\
\hline Leu & $\%$ & 6.50 \\
\hline Tyr & $\%$ & 3.24 \\
\hline Phe & $\%$ & 4.24 \\
\hline His & $\%$ & 3.32 \\
\hline Lys & $\%$ & 4.76 \\
\hline Arg & $\%$ & 10.12 \\
\hline Total amino acids: & $\%$ & 39.29 \\
\hline $\mathrm{Ca}$ & g/kg DM & 2.95 \\
\hline K & g/kg DM & 12.66 \\
\hline $\mathrm{P}$ & g/kg DM & 7.47 \\
\hline $\mathrm{Na}$ & g/kg DM & 0.08 \\
\hline $\mathrm{Mg}$ & g/kg DM & 3.14 \\
\hline $\mathrm{Mn}$ & g/kg DM & 0.08 \\
\hline $\mathrm{Cu}$ & g/kg DM & 0.02 \\
\hline $\mathrm{Fe}$ & g/kg DM & 0.13 \\
\hline $\mathrm{Zn}$ & g/kg DM & 0.07 \\
\hline Total alkaloids: & $\mathrm{mg} / \mathrm{kg}$ & 270 \\
\hline Angustifoline & $\%$ & - \\
\hline Isolupanine & $\%$ & - \\
\hline Lupanine & $\%$ & - \\
\hline 130H Lupanine & $\%$ & - \\
\hline Sparteine & $\%$ & 33.60 \\
\hline Lupinine & $\%$ & 63.29 \\
\hline Oligosaccharides & g/kg DM & 8.56 \\
\hline Raffinose & g/kg DM & 1.10 \\
\hline Stachyose & g/kg DM & 4.94 \\
\hline Verbascose & g/kg DM & 2.53 \\
\hline P-phytate & $\%$ & 0.70 \\
\hline
\end{tabular}

Table 10. Chemical composition of yellow lupin seeds, cultivar Mister.

Table 10. The chemical composition of rapeseed meal was not presented since it was not the main objective of the study. To supplement nutrients in each treatment group, between weeks 2 and 8 birds received powder product containing amino acids and vitamins (dose $125 \mathrm{~g} / 1,000 \mathrm{~L}$ drinking water, Amino-Vitasol WSP, Medivet), as well as SELVITA Vitamin E + Selenium (INVESA) at a dose of 1,000 ml/ 4,000 ldrinking water between weeks 5 and 8. Supplementation was the same in all groups. 
Growth performance. Ducks were reared to 8 weeks of age, consistently with the generally used technology for rearing broiler ducks. Birds were reared in a semi-intensive system and received feed ad libitum. Total feed intake was recorded each week in each group, and the mean feed intake was calculated. The body weight of birds in all groups was measured each week (WLC 12/F1/R scales, Radwag) with accuracy to the nearest $\pm 0.2 \mathrm{~g}$. Weekly feed intake $(\mathrm{g})$ and body weight $(\mathrm{g})$ were used to calculate the feed conversion ratio per kg of body weight gain (FCR, \%). The mortality rate was calculated at the end of the duck rearing period. Gathered data were used to calculate the European Broiler Index (EBI) from the formula:

$$
\mathrm{EBI}=[\mathrm{LBW} \times \mathrm{SR} / \mathrm{AB} \times \mathrm{FCR}] \times 100
$$

where: LBW—-live body weight at the end of duck rearing $(\mathrm{kg}), \mathrm{SR}$ - survival rate (\%), AB—age of birds (days), FCR-feed intake per $\mathrm{kg}$ of body weight $(\mathrm{kg})$.

Carcass and meat traits. Birds were slaughtered at the age of 8 weeks. Ducks were stunned by electricity, and then their heads were cut off (quick bleeding), according to the requirements. The fasting of birds before slaughter lasted $12 \mathrm{~h}$. Five males and five females were selected from each group, with a body weight close to the mean weight of the same sex individuals in their group. Zoometric traits were measured post-mortem with accuracy to the nearest $1 \mathrm{~mm}$ : the length of the abdomen with neck (between the first cervical vertebra and the posterior margin of the ischium), the length of the abdomen (between the shoulder joint and the posterior margin of the ischium), the length of the sternum crest (from the anterior to the posterior margin), the length of the shank (between the ankle joint and the lower posterior surface of the first toe at its base), and the chest circumference (behind the wings, along the anterior margin of the sternum crest and the middle thoracic vertebra). Gathered data were used to calculate body conformation indices (\%): compactness index (ratio of chest circumference to abdomen length in $\mathrm{cm}$ ), massiveness index (body weight in $\mathrm{kg}$ to abdomen length in $\mathrm{cm}$ ), and long-leggedness index (shank length to abdomen length in $\mathrm{cm}$ ). The carcasses were gutted. Using a $\mathrm{pH}$-meter (CP-401, ELMETRON, with an OSH 2,105 knife electrode) with accuracy to the nearest $\pm 0.01 \mathrm{pH}$ of breast muscle were done. The electrode was inserted at a $45^{\circ}$ angle into the right superficial breast muscle. Measurement of carcass $\mathrm{pH}$ was after $24 \mathrm{~h}$ of cold storage at $+4^{\circ} \mathrm{C}(\mathrm{pH} 24)$. Duck carcasses were dissected at a laboratory using the simplified method described by Ziołecki and Doruchowski ${ }^{40}$. The following elements of carcass were weighed (g): carcass with neck, neck, wings, skin with subcutaneous fat, abdominal fat, breast muscles, leg muscles, carcass remains and offal. Carcass elements were weighed on a WLC 12/F1/R scales (Radwag) with accuracy to the nearest $\pm 0.2 \mathrm{~g}$, and their proportions in the weight of gutted carcass with neck were calculated in $\%$. The weight of gutted carcass without offal ( $\mathrm{g}$ ) and body weight before slaughter $(\mathrm{g})$ were used for the calculation of the dressing percentage $(\mathrm{g})$ of birds according to the formula:

$$
\mathrm{Dp}=[\text { weight of gutted carcass without offal }(\mathrm{g}) \text { /body weight before slaughter }(\mathrm{g})] \times 100
$$

For physicochemical analysis 10 ( 5 males and 5 females) breast and legs muscles from each group were taken. Each piece was assigned by number. Breast and leg muscles were analysed without skin. The outer right part of breast muscles, leg muscles and skin were analysed for colour using a colorimeter (CR 400, Minolta) in the CIE L* $\mathrm{a}^{\star} \mathrm{b}^{\star}$ system ${ }^{41}$. Drip loss from breast and leg muscles was measured. For that purpose, right breast muscles and leg muscles were sampled and weighed on a PS 750/X scales (Radwag) with accuracy to the nearest $\pm 0.1 \mathrm{~g}$, attached to a special stand and left for $24 \mathrm{~h}$ in a cold room at $4{ }^{\circ} \mathrm{C}$, weighed again, and drip loss in $\%$ was calculated based on the difference in muscle weight before and after storage ${ }^{42}$. The water-holding capacity of breast and leg muscles was analysed with the Grau and Hamm method ${ }^{43}$. Muscles were disintegrated (K35 mincer, Electrolux), and 280 to $320 \mathrm{mg}$ samples were weighed with accuracy to the nearest $\pm 0.01 \mathrm{mg}$ (Radwag PS 750/X scales), wrapped in filter paper, placed between two glass plates and kept under $2 \mathrm{~kg}$ pressure for 5 min. Samples were weighted again after $5 \mathrm{~min}$. Water-holding capacity (\%) was calculated as the ratio of sample weight after pressing to its weight before pressing $(\mathrm{mg})$. Cooking loss from breast and leg muscles (without skin) was analysed. Muscles were disintegrated in a mincer (K35, Electrolux) and $20 \mathrm{~g}$ samples were weighed (Radwag PS $750 / \mathrm{X}$ ). Samples were wrapped in sterile gauze, tied with string, placed in an $80^{\circ} \mathrm{C}$ water bath (ADVERTI) for $30 \mathrm{~min}$, and weighed again (PS 750/X). The difference in weight was used to calculate heat-induced leakage from muscles (\%). Carcass and meat quality analysis were done according to the methods described by Biesek et al. ${ }^{9}$.

Fatty acid composition. Samples of subcutaneous and abdominal fat from ducks were preserved, frozen $\left(-18^{\circ} \mathrm{C}\right)$, lyophilized (Alpha plus apparatus, Donserv) and analysed for fatty acid composition.

Fat was extracted using a technique proposed by Folch et al. ${ }^{44}$, with a mixture of chloroform and methanol $(2: 1 \mathrm{v} / \mathrm{v})$ on a laboratory shaker. The samples were filtered and left for $24 \mathrm{~h}$ for decantation. Fatty acid methyl esters were prepared according to the PN-EN ISO 12,966-2 standard ${ }^{45}$. The fat was dissolved in isooctane and transmethylated with a solution of potassium hydroxide in methanol. Then neutralization of potassium hydroxide with sodium sulphate was carried out. The esters were salted with sodium chloride solution.

Saponified fatty acid esters were separated using a gas chromatograph (type 7,890 B, Agilent Technologies) with an MSD 5977A detector and an autosampler. A capillary column DB-225 MS $60 \mathrm{~m} \times 0.25 \mathrm{~mm} \times 0.25 \mu \mathrm{m}$ was used for analysis. Analytical parameters were as follows: injection port temperature (split mode $1: 100$ ) $230^{\circ} \mathrm{C}$; transfer line temperature $230^{\circ} \mathrm{C}$, ion source temperature $230{ }^{\circ} \mathrm{C}$; quadrupole temperature $150{ }^{\circ} \mathrm{C}$, mode: SIM, ionization type: EI. Oven temperature settings were: $70^{\circ} \mathrm{C}$-increase $0.0^{\circ} \mathrm{C} / \mathrm{min}$-hold time $0.0 \mathrm{~min} ; 210^{\circ} \mathrm{C}-$ increase $7.0^{\circ} \mathrm{C} / \mathrm{min}$ - hold time $-65.0 \mathrm{~min}$. Carrier gas—helium (flow rate $1.0 \mathrm{ml} / \mathrm{min}$; volume of injected sample $1.0 \mu \mathrm{l}$ ). Fatty acid methyl esters were identified using the Supelco 37 standard FAME Mix component. 
The individual fatty acids were calculated as the percentage of the total fatty acids identified. Method of fatty acid composition analysis was done similarly, as Kuźniacka et al. ${ }^{6}$ described.

Statistical analysis. Data were processed using Statistica 12.5 PL software, 2017. Mean values for all analysed parameters and their standard deviations (SD) and coefficients of variation (v) were calculated. A two-way model of ANOVA was used to analyse variability (variable 1-dietary treatment group, variable 2 - sex). The significance of differences was verified using the Tukey test. Interactions between experimental variables were determined. The significance of differences was adopted at $P \leq 0.05$. Production results were calculated for the whole flock of ducks, but the quality of meat traits were calculated for chosen ducks for the slaughter.

Ethics. The research were done with recommendations of Directive No. 2010/63/EU and resolution 13/2016 of the National Ethics Committee for Animal Experiments of June 17, 2016. The approval of Ethic Committee was not required. The slaughter of birds was carried out in accordance with the applicable rules on the handling of animals at the time of slaughter, including humane treatment. Also the methods used in the meat quality tests were carried out in accordance with the current and commonly used methods described in the Material and methods section.

Received: 7 May 2020; Accepted: 30 July 2020

Published online: 10 August 2020

\section{References}

1. Ding, S. et al. Comparison of carcass and meat quality traits between lean and fat Pekin ducks. Asian Austral. J. Anim. https://doi. org/10.5713/ajas.19.0612 (2019).

2. Zheng, A. J. et al. Unraveling molecular mechanistic differences in liver metabolism between lean and fat lines of Pekin ducks (Anas platyrhynchos domestica): a proteomic study. J. Proteom. 98, 271-288. https://doi.org/10.1016/j.jprot.2013.12.021 (2014).

3. Zhang, Z. et al. Genomic variation in Pekin duck populations developed in three different countries as revealed by whole-genome data. Anim. Genet. 49, 132-136. https://doi.org/10.1111/age.12639 (2018).

4. Qamar, S. H. et al. Effect of oil supplementation on growth performance, meat quality and antioxidative ability in meat ducks fed a diet containing aging corn. Int. J. Agric. Biol. 21, 201-208. https://doi.org/10.17957/IJAB/15.0882 (2019).

5. Ao, X. \& Kim, I. H. Effects of dietary lipid sources on growth performance and carcass traits in Pekin ducks. Poult. Sci. 99, 499-504. https://doi.org/10.3382/ps/pez558 (2020).

6. Kuźniacka, J., Banaszak, M., Biesek, J., Maiorano, G. \& Adamski, M. Effect of faba bean-based diets on the meat quality and fatty acids composition in breast muscles of broiler chickens. Sci. Rep. 10, 5292. https://doi.org/10.1038/s41598-020-62282-7 (2020).

7. Rutkowski, A., Kaczmarek, S. A., Hejdysz, M., Nowaczewski, S. \& Jamroz, D. Concentrates made from legume seeds (Lupinus angustifolius, Lupinus luteus and Pisum sativum) and rapeseed meal as protein sources in laying hen diets. Ann. Anim. Sci. 15, 129-142. https://doi.org/10.2478/aoas-2014-0061 (2015).

8. Hejdysz, M., Kaczmarek, S. A. \& Rutkowski, A. Factors affecting the nutritional value of pea (Pisum sativum) for broilers. J. Anim. Feed Sci. 24, 252-259 (2015).

9. Biesek, J., Kuźniacka, J., Banaszak, M. \& Adamski, M. The quality of carcass and meat from geese fed diets with or without soybean meal. Animals 10, 200. https://doi.org/10.3390/ani10020200 (2020).

10. Piasecka-Józwiak, K., Księżak, J., Słowik, E. \& Chabłowska, B. The use of lupin flour as nutritional additive to organic wheat sourdough bread. J. Res. Appl. Agric. Eng. 63, 56-61 (2018).

11. Kaczmarek, S. A., Hejdysz, M., Kubiś, M. \& Rutkowski, A. Influence of graded inclusion of white lupin (Lupinus albus) meal on performance, nutrient digestibility and intestinal morphology of broiler chickens. Br. Poult. Sci. 57, 364-274 (2016).

12. Kuźniacka, J. et al. Quality and physicochemical traits of carcasses and meat from geese fed with lupin-rich feed. Animals 10, 519. https://doi.org/10.3390/ani10030519 (2020).

13. Hang, L. et al. High vitamin levels ameliorate negative effect of rapeseed meal in meat ducks by improving antioxidant activity. Poult. Sci. 10, 4622-4631. https://doi.org/10.3382/ps/pez160 (2019).

14. Recoules, E. et al. Digestion dynamics in broilers fed rapeseed meal. Sci. Rep. 9, 3052. https://doi.org/10.1038/s41598-019-38725 -1 (2019).

15. Banaszak, M., Kuźniacka, J., Biesek, J., Maiorano, G. \& Adamski, M. Meat quality traits and fatty acid composition of breast muscles from ducks fed with yellow lupin. Animal https://doi.org/10.1017/S1751731120000610 (2020).

16. Wężyk, S., Herbut, E. \& Wawrzycki, M. Dobra pasza z „Dobropaszu”. Polskie Drobiarstwo 9, 30 (1996) ((in Polish)).

17. Zduńczyk, Z. et al. Beneficial effects of increasing dietary levels of yellow lupine (Lupinus luteus) seed meal on productivity parameters and gastrointestinal tract physiology in eight-week-old turkeys. Anim. Feed Sci. Technol. 2011, 189-198 (2016).

18. Hejdysz, M. et al. Effect of increasing levels of raw and extruded narrow-leafed Lupin seeds in broiler diet on performance parameters, nutrient digestibility and $\mathrm{AME}_{\mathrm{N}}$ value of diet. Anim. Feed Sci. 27, 55-64 (2018).

19. Kuźniacka, J., Zmudzińska-Pietrzak, A., Roślewska, A., Banaszak, M. \& Adamski, M. Effect of native high-protein feeds on the animal products' quality. Nutritive recommendations due to the use of native high-protein plant feeds for pigs and poultry. Wyd. APRA, Bydgoszcz, pp. 135-151 (2017). (in Polish)

20. Biesiada-Drzazga, B., Charuta, A., Janocha, A. \& Łęczycka, J. Assessment of slaughter value of Pekin STAR 53 HY ducks. Rocz. Nauk. PTZ. 7, 109-116 (2010) ((in Polish)).

21. Mierlita, D. \& Popovici, D. Effect of partial substitution of soybean meal with lupin seeds on growth and economic efficiency of broilers. Lucrari Stiintifice Seria Zootehnie. 59, 60-65 (2013).

22. Suchỳ, P. et al. Effect of replacing soybean meal with lupin seed-based meal in chicken diet on performance, carcass value and meat quality. Acta Vet. Brno. 79, 195-202 (2010).

23. Kokoszyński, D. \& Bernacki, Z. Comparison of slaughter value of Pekin ducks from two conservative flocks. J. Cent. Eur. Agric. 21, 217-225 (2011).

24. Witak, B., Górski, J. \& Górska, A. The effect of yellow lupine meal and extracted rapeseed meal on carcass composition and some characteristics of meat quality of 7-week-old ducks of strain A44. EPC 2006-12th European Poultry Conference Verona, Italy, 10-14 September. 13, 363 (2006).

25. Kokoszyński, D. et al. Comparison of growth performance and meat traits in Pekin ducks from different genotypes. Eur. Poult. Sci. 93, 1993-1999 (2015).

26. Gardzielewska, J., Jakubowski, M., Karamucki, T., Rybarczyk, A. \& Natalczyk-Szymkowska, W. Comparison of carcass and meat quality from 17-weeks and 3-years old geese. Rocz. Nauk. PTZ. 2, 147-155 (2009) ((in Polish)). 
27. Okruszek, A. et al. Changes in selected physicochemical parameters of breast muscles of geese from Polish conservation flocks depending on duration of the post slaughter period. Arch. Tierz. Dummerstorf. 51, 255-265 (2008).

28. Pietrzak, D. et al. Influence of nutrition and sex on the choosen quality traits of meat from White Kołuda geese. Zesz. Probl. Post. Nauk Roln. 574, 49-56 (2013) ((in Polish)).

29. Krawczyk, M., Mikulski, D., Przywitowski, M. \& Jankowski, J. The effect of dietary yellow lupin (L. luteus cv. Baryt) on growth performance, carcass characteristics, meat quality and selected serum parameters of turkeys. J. Anim. Feed Sci. 24, 61-70 (2015).

30. Wu, P., Wen, C., Leng, Z. X. \& Zhou, Y. M. Effect of oolong tea (Camellia sinensis) powder particle size on growth performance, fat deposition, meat quality and antioxidant activity in meat ducks. Anim. Feed Sci. Technol. 194, 131-135 (2014).

31. Biesiada-Drzazga, B. Analysis of nutrition' effect on the chemical composition of chosen muscles and fatty acid profile from skin with subcutaneous fat and abdominal fat from broiler geese. Acta Sci. Pol. Zootech. 5, 3-12 (2006).

32. Biesiada-Drzazga, B. Influence of feeding by feed with sunflower meal and yellow lupin on the quality of muscle tissue and fat. Rocz. Inst. Przem. Mięs. Tłuszcz. 46, 25-33 (2008).

33. Mehaffey, J. M., Pradhan, S. P., Meullenet, J. F., Mekee, S. R. \& Owens, C. M. Meat quality evaluation of minimaly aged broiler breast fillets from five commercial genetic strains. Poult. Sci. 85, 902-908 (2006).

34. RothMaier, D. A. \& Kirchgessner, M. Composition and nutritive-value of various white and yellow lupin varieties (Lupinus-albus L. and Lupinus-Luteus L.) for pigs and poultry. Agribiol Res-Zeitschrift fur Agrarbiologie Agrikulturchemie Okologie. 46, 218-228 (1993).

35. Mieczkowska, A. \& Smulikowska, S. The influence of white lupin seeds in diets supplemented with fats of animal or plant origin on the fatty acid composition of broiler tissues. J. Anim. Feed Sci. 14, 93-107 (2005).

36. Biesiada-Drzazga, B. The effect of feeding on muscle tissue, skin and fat composition in broiler geese. Proceedings of XVIIIth International Poultry Symposium PB WPSA "Science for practice-practice for science". Rogów, Poland, 266-273 (2006b).

37. Karpińska, M. \& Batura, J. Effect of age, place in organism and sex on the quality of deposited fat in Italian White geese. Zesz. Nauk. Prz. Hod. 36, 333-342 (1998).

38. Biesiada-Drzazga, B., Grużewska, A., Janocha, A. \& Markowska, M. Analysis of application of concentrated mixtures containing soybean extracted meal and sunflower meal in goose broiler feeding. Arch. Geflugelk. 74, 109-115 (2010).

39. Kiczorowska, B., Samolińska, W. \& Andrejko, D. Effect of micronized pea seeds (Pisum sativum L.) as a substitute of soybean meal on tissue fatty acid composition and quality of broiler chicken meat. Anim. Sci. J. 87, 1396-1406 (2016).

40. Ziołecki, J. \& Doruchowski, W. Methods for the evaluation of meat quality and yield. Publisher COBRD Poznań: 1-22 (1989). (in Polish)

41. CIE. Colorimetry. Publication CIE 15.2. Vienna: Central Bureau of CIE, (1986).

42. Honikel, K. O. The water binding of meat. Fleischwirtschaft 67, 1098-1102 (1987).

43. Grau, R. \& Hamm, R. Eine einfache Methode zur Bestimmung der Wasserbindung in Fleisch. Fleischwirt. 4, 295-297 (1952).

44. Folch, J., Less, M. \& Stanley, G. H. S. A simple method for the isolation and purification of total lipids from animal tissue. J. Biol. Chem. 226, 497-509 (1957).

45. PN-EN ISO 12966-2:2011. Vegetable and animal oils and fats. Gas chromatography of fatty acid methyl esters. Preparation of fatty acid methyl esters (2011). (in Polish)

\section{Acknowledgements}

The study was carried out under measure 4.4 "Qualitative assessment of animal raw materials produced based on domestic sources of vegetable protein" of the Multiannual Programme "Increased use of domestic feed protein for the production of high-quality animal products under the conditions of sustainable development" [Resolution 222/2015].

\section{Author contributions}

All authors took part in meat quality analysis. E.K., M.A., J.K.,-designed of experiment, E.K., J.K.G., J.K., M.B., J.B., analyzed physicochemical traits, E.K., J.K.G., analyzed chemical traits in breast muscles, J.K., M.B., J.B., M.A., analyzed data, E.K., J.K.G., J.B., wrote the paper with cooperation with all of authors. All authors approved the final manuscript.

\section{Competing interests}

The authors declare no competing interests.

\section{Additional information}

Correspondence and requests for materials should be addressed to J.B.

Reprints and permissions information is available at www.nature.com/reprints.

Publisher's note Springer Nature remains neutral with regard to jurisdictional claims in published maps and institutional affiliations.

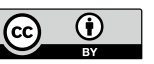

Open Access This article is licensed under a Creative Commons Attribution 4.0 International License, which permits use, sharing, adaptation, distribution and reproduction in any medium or format, as long as you give appropriate credit to the original author(s) and the source, provide a link to the Creative Commons license, and indicate if changes were made. The images or other third party material in this article are included in the article's Creative Commons license, unless indicated otherwise in a credit line to the material. If material is not included in the article's Creative Commons license and your intended use is not permitted by statutory regulation or exceeds the permitted use, you will need to obtain permission directly from the copyright holder. To view a copy of this license, visit http://creativecommons.org/licenses/by/4.0/.

(c) The Author(s) 2020 